\title{
On the origin, use and destination of human embryos
}

\author{
Evert van Leeuwen \\ Center of Ethics and Philosophy, VU Medical Center, Van der Boechorststraat 7, 1081 BT Amsterdam, The Netherlands \\ (Correspondence should be addressed to Evan Leeuwen; Email: e.vanleeuwen@vumc.nl)
}

\begin{abstract}
The moral acceptability or non-acceptability of the use of human embryos in research raises questions on several philosophical levels. The mixing-up of these levels results in strongly defended and endless debates. In this contribution, arguments on three levels will be discussed, the ontological, the practical and instrumental and the level of human relationships. It is concluded that, on the latter level, the moral problems of the other two are significant, but not conclusive. The decision to allow or to ban research with human embryos is charged with full human responsibility.
\end{abstract}

European Journal of Endocrinology 151 U13-U16

\section{Philosophical introduction}

During the last 50 years science and technology have presented us with all kinds of technology disclosing new types of reality. Most of these realities depend for their existence on the way science and technology present them. Especially in biomedicine, we learn more about ourselves and our biological reality by studying, manipulating and changing what we are, with the restriction of technological and scientific conditions. Do these technological processes result in knowledge of what a human being really is or do we have to admit that this knowledge is partial and needs to be integrated into larger, for instance, clinical settings, in order to become morally meaningful? In many cases, we defend the progress of biomedical research by making claims in such larger settings. Research with human embryos is, for example, defended by its possible successful use in the clinical therapy of diseases like diabetes, Parkinson's disease and spinal cord lesions (1). Such claims presuppose a continuity between the concepts we use in laboratories and in scientific thinking and those we use in everyday life. As a consequence, the moral value they have on the level of everyday life is easily projected into the world of microscopic realities. In this way, a cellular human being, an embryo, can be ascribed human personhood as a consequence of thinking in continuities. Of course, almost no one who declares that human embryos are endowed with personhood does consider the embryo to be a person. The ascription allows no more than that we treat the embryo 'as if' it is a human person. 'As if' reasoning then takes the place of concrete deliberation. The problems attached to 'as if' reasoning in biology have puzzled philosophers for almost a century $(2-5)$.

For many scientists the 'as if' character of moral reasoning is hyperbolic and forced. Although they do accept the continuity of thinking from their own scientific field into broader settings, as in promising clinical success, they do not accept reciprocal reasoning in moral guidelines and rules when it comes down to the embryo itself. However, it should not be forgotten that the biotechnological reality is the result of human enterprise and therefore makes us responsible for what we do with it. Human embryos in other words are not "just there'. They can only exist outside the female womb because we have sufficient control over the necessary conditions. In other words, the origin of their reality has been human action and decision making.

One way out of this problematic situation is to take our responsibility seriously in developing moral guidelines that suit both the technological realities we create in laboratories as well as their moral consequences in the broader domains of daily clinical life. In this way, we may rule out 'as if' reasoning and start by making prudent and concrete moral deliberations concerning the use of the biotechnological realities. First, we have to analyze the moral value of those realities in different settings and then we have to study how these values are connected to our everyday moral practices. Two levels of reasoning are then directly relevant: those of ontological and instrumental reasoning.

\section{Ontological arguments}

The keyword in ontological arguments concerning human embryos is 'moral status'. The term is used by Mary Anne Warner (6) in determining the moral status of the human embryo. The word 'status' in this context is most intriguing in its connection with morality. According to Webster's Dictionary 'status' has three meanings: (i) the rank or position within a hierarchy, (ii) the condition of something or some being in the eyes of the law, (iii) the state or condition of something or being with respect to circumstances. With respect to 'moral status' the first two meanings seem to be most appropriate. The moral status of the human embryo can then be defined as the ranking of 
the human embryo in a hierarchy of morally respectful beings, protected by law. This definition consequently creates the need to assess the moral ranking. Warner develops seven principles or criteria to do so and in this way she attributes or ascribes moral respect to the entity of a human being (6).

This process of attribution or ascription has to do with the ontological perspective on the human embryo and the way in which its existence is made possible in biotechnology. The existence of the human embryo outside the womb is in itself a human artefact and its being is totally dependent on the circumstances in a scientific and technological context. Outside the womb it cannot develop into a fetus, a child or an adult. It lacks the necessary environment that is able to control its growth and development. But it can still be described as 'a human being' (a human embryo differs from those of pigs, apes etc.). This abstract description corresponds with the meaning of the word 'ontology', or theory of being, as was defined in the age of Descartes: a uniform scientific and metaphysical theory of being that is stripped from every kind of essence or intrinsic meaning. (Goclenius probably coined the word in his lexicon (7).) Moral and other meanings are, according to that theory, the result of human activities in attribution and ascription. However, this is not what the ontological arguments about moral status try to prove. They want to show exactly the opposite, namely that human embryos have some kind of intrinsic meaning that excludes them from being part of any human activity other than procreation. In order to make this possible, the term 'human being' accrues a general, abstract moral significance. The type of reasoning then becomes as follows: a human embryo is (at some stage of its development) a human being. All human beings deserve the same kind of moral respect. Therefore, human embryos deserve the same respect as we give to other human beings.

Discussion is, of course, still possible about the brackets (at some stage of development) in the first clause. Some will say that the human embryo is in full human existence at the moment of the fusion of gametes, others will say that it takes 14 days, again others might say that it takes 41 days. These possibilities do not, however, change the basic structure that identifies a human embryo as a human being that deserves the same respect as every human being. As Gómez-Lobo (8) recently stated: 'I have developed continuously and gradually, without gaps, from the embryo that was conceived by my parents. If I trace my life back through space and time, I arrive at that embryo... and this is confirmed by the fact that...I have the same genome that I had when I was conceived'.

Besides identity (sameness), continuity in time and potentiality or capacity to grow are considered to be included within the concept of human being. Each of these properties, sameness, continuity and potentiality, thus link our daily existence with the human embryo in the laboratory; a link that is established by the shift of the moral meaning of persons to an abstract, logical description of an entity. From biology we know that the human embryo does not stay the same and possesses only a partial genetic identity. Furthermore, its continuity of being depends on its relations with the surrounding environment. It has only potentiality or capacity when it is being cared for in a favorable surrounding like the womb. In other words, we cannot treat the human embryo outside the womb 'as if' it were inside a womb. Outside the womb it has only a limited chance of survival that has to be provided by the environment. One might even say that it has a totally different status of being, and thus a different moral status. The womb is more than a separating wall or a protection bag.

\section{Practical, instrumental arguments}

The separation between the human embryo and the womb has, of course, not very much significance in the daily practice of in vitro fertilization (IVF). Embryos are being created on purpose, artificially, outside the womb. The embryos might even develop in a new environment as in the case of egg donation and surrogate motherhood. Separating embryos from the womb makes this possible, but in due course it is hoped that the embryo will develop like any other. It has the same, perhaps even more, moral value as in a normal pregnancy. Still, the act of separation makes it possible to look at an embryo as a special kind of human tissue. Most of the ethicists and scientists who defend the instrumental position do not adhere to this view. They do not embrace the possible reduction of an embryo to a tiny piece of cellular tissue. They acknowledge that human embryos deserve some amount of special respect, albeit a low status ranking, and then proceed by arguing that it is permissible to use them for goals with higher moral value. This debate of means-to-an-end gives the human embryo an instrumental value that has to be measured by looking at the goal for which it is used. When specific conditions are fulfilled, the goal can be attained by using embryos. As De Wert \& Mummery (1) state: 'Research into the development of cell-replacement therapy requires the instrumental use of pre-implementation embryos from which hES cells are derived since current technology requires lysis of the trophectoderm and culture of the inner cell mass; the embryo disintegrates and is thus destroyed. ... The dominant view in ethics is that the instrumental use of pre-implementation embryos, in the light of their relative moral value, can be justified under certain conditions.'

So we have to look for the conditions that enable us to make an instrumental use of the embryos. This search for conditions or criteria takes time and causes all kinds of 
debate. In the background stands the moral status, but the debate will concentrate itself on issues of possible risk, success and so on. Utilitarian reasoning, in which the possible happiness of the many takes precedence over the luck of an individual, is combined with questions concerning the conditions in which the goal justifies the means. An example is given by Meilander (9). He looks for the justification of the conditions in moral theories of 'just war'. In wartime as well as in cases of triage medicine, one has to make decisions to sacrifice human beings in order to save others and the community. Means that are normally considered as immoral, can thus be justified (9). (Meilander rejects the comparison but accepts its possibility.)

It seems, however, rather awkward to compare the research on human embryos and human embryonic stem cells (hES) with a situation of war and compelling needs. One misses the element of force majeure. Another example is given by McGee \& Caplan (10). They do suggest force majeure and argue that hES research will, in the end, relieve humanity from endless suffering from many diseases. The possibilities of transplantation medicine especially warrant such high expectations in their view. Therefore, granting the low moral status of the human embryo, they argue that their use is justified on the 'moral imperative of compassion' (10). In an almost grotesque way they claim that half the human race can be saved by the use of hES research. In fact, they acknowledge the ontological basis of (low) moral status, but they justify their use in the same way as everyone who uses an instrumental argument: a straight utilitarian calculation with numbers as large as possible.

As mentioned previously, the ontological argument still has a place in the background of these and most other instrumental approaches. Unlike the old discussion on abortion, the perspective of the human embryo as a piece of human tissue is almost absent. This view has been weakly defended in the work of Helga Kuhse and Peter Singer (11). They expand respect for human life to animal life and the protection of human life becomes then mixed up in an ontological argument on what life is. In doing so, they try to develop conditions for human respect that might equalize their respect for other living beings. Like any other instrumental approach of the moral value of human embryos, or human life as such, they have to deal with the justification of means and ends. That justification becomes quite arbitrary, for instance when we connect personhood with consciousness or the psychological selfhood. This arbitrariness is formulated as a question of how to set limits in using different forms of life, including rodents and human embryos. Talk about limits suggests that it is possible to draw a line between respect and the possible use in research of transplantation medicine. In this way, the discussion about means and goals is avoided, although it will return when circumstances and new perspectives force us. The discussion of means and ends is therefore not only visible in the issues of "just war' but likewise in disputes over moral limits and competition between research groups all over the world. The setting of the limits depends on a human decision that can always be withdrawn. The limits are not set by the human embryo. Setting limits can therefore only be considered as an act of human responsibility.

\section{Relational arguments}

Morals and ethics can be considered as typically human endeavors that take moral intentionality and responsibility into account. Animals, ants or donkeys, do have and develop rules of conducts and strategies for survival, but it is an oxymoron to endow ants or donkeys with moral intentional and responsible behavior (12). Science and technology have neglected the moral dimension of their endeavor for quite some time. The dominant perspective has been that science and technology only depend on conditions regarding truth or likelihood in theoretical thinking. This kind of thinking is recognizable in the above-mentioned ontological approach: it considers reality only in so far as it corresponds to abstract reasoning.

During the last century we have learned and experienced that this approach fails when it comes to the ways in which science and technology are used. That use does not merely fit the world as it really is, but instead changes the world. Nowadays we know that the growth of science and technology changes the climate and the differentiation of life on this planet. In other words, we are becoming aware that our knowledge makes us responsible for the world as it is and will become. Even unknown living beings in the Amazon rainforests or in the deep oceans have become dependent on our interventions in this world.

The awareness of this moral responsibility can easily lead to conservative and even hostile views on the development of science and technology. Moral debates in biotechnology then become intertwined with ideological and political motives ending in struggles for power, control and legislation. Such struggles can only be avoided if we are prepared to realize that success in science and technology depends not only on criteria belonging to the abstract fields of laboratories and experiments but also, and perhaps even more so, on the ways we are dealing with that success in daily life. Within the latter area, responsibility and intentionality come into play as we can see when we deal with human embryos.

So when we consider, on the one hand, the embryo that is growing in the womb and cared for by its future parent(s), the human relationship in which the embryo originates and grows is morally speaking as important as the biological conditions, like nutrients and hormones. The desire for a child makes the mother already invest love and care for a being that is still unable to feel pain, joy or sorrow. The embryo does not 'deserve' this respect, it lives because of this respect and is valued 
as the beginning of a new life. The same goes for human embryos that are created by means of IVF. Although the embryo still has a large chance of perishing, it is at the same time the result of enormous human efforts and is prudently cared for by the people who have to deal with it until it is placed in the womb. That human embryo is perhaps even more respected than an embryo that results from human intercourse.

In both cases, we deal with embryos that originate in our respect for life, not because of what they are but because of what parents and others hope them to be. They originate in one of the most intimate kinds of human relationship in which most people feel themselves extremely responsible and emotionally involved. Regarding this respect, it does not matter whether the embryo lives in so-called natural circumstances or in the technological surrounding of a freezer. It is not what it is, but how it is dealt with within the human relationship, that makes the difference.

On the other hand, we have to consider human embryos that are not part of the highly moral relationship of human reproduction, maybe because they are spare embryos that are left over after the IVF has been successful and perhaps even because they are created with no intention of letting them grow into childhood. In these cases, the morality of reproduction is not in place and the embryos become part of other processes of human decision making and human responsibility. In the case of a spare embryo, it is still the same being as it was when, perhaps a few months ago, it was considered to be a candidate for placement in the womb. That 'being the same' has, however, only a biological meaning. Because it will not be replaced, it has lost its capacity to grow into a human being. It will not be offered the necessary nutrients and hormones and it does not or no longer participate in human pregnancy and expectation. This fact makes it essentially different from neonates or even abandoned children.

Still, it does deserve human respect. It still is part of a network of human relationships. It does therefore deserve responsible decision making about what will be done with it. In this sense, it is not left to arbitrary thinking and handling. Because we realize that the human embryo, even if it is not to be placed in a womb, is still embedded in human relationships and depends on them for its survival, it challenges us to take responsibility. This challenge to humanity is considered by Levinas as the fundamental non-ontological ground of ethics. The scope of this article does not allow the pursuit of his thinking, but a simple way of putting the same thing has been done by Buber (13) when he stated that it belongs to humans to be able to create I-Thou relations instead of I-It relations. Researchers tell stories about their relations with their laboratory animals that corroborate this view.

That means that use of the embryo therefore has to be subjected to conscious ethical decision making. When embryos are used within the laboratory, the goals and means have to be assessed according to the ethics of research and biotechnology. Possible use outside the laboratory should also be assessed by social rules including laws. Not because human embryos are to be treated as beings they are not - like persons - but because they participate in a scientific encounter as living beings. That is why they challenge our sense of moral respect. In this way, research with human embryos is morally possible like any other kind of biotechnological experiment. The questions of how the embryos are dealt with and to what purpose have, however, to be settled in conscientious processes of moral decision making that take into regard all scientific and technological possibilities.

\section{Conclusion}

Human embryos can nowadays be kept alive outside the womb. In that case they are subjected to human decision making about what will be done with them. As long as there is an intention to place them into a womb, they are respected as potentially human beings. If this is not the case, they must be dealt with as they are: human cells with great potential. Whether or not we are to make use of that potential is a matter of adequate scientific and moral thinking that always takes into account that the embryo is placed in that position by human action.

\section{References}

1 De Wert G \& Mummery C. Human embryonic stem cells: research, ethics and policy. Human Reproduction $200318672-682$.

2 James W. The will to believe and other writings. New York: Doubleday, 1995.

3 Vaihinger H. Die Philosophie des Als Ob: System der theoretische, praktische und religiosen Fiktionen der Menschheit auf Grund eines idealistiche Positivismusit einem Anhabg über Kant und Nietzsche. Berlin: Reuther, 1913.

4 Heidegger M. What is a thing? Chicago: Gateway, 1970.

5 Bergson H. Matter and memory. New York: Zone Books, 1968.

6 Warren MA. Moral Status: Obligations to Persons and Other Living Things, pp 147-178. Oxford: Oxford University Press, 1997.

7 Leeuwen E. van Descartes' Reguale, pp 210-213. Amsterdam: VUUP, 1987.

8 Gómes-Lobo A. On the ethical evaluation of stem cell research. Kennedy Institute of Ethics Journal 200414 77-78.

9 Meilaender G. The point of a ban: or, how to think about stem cell research. Hastings Center Report 200131 9-16.

10 McGee G \& Caplan A. The ethics and politics of small sacrifices in stem cell research. Kennedy Institute of Ethics Journal 19909 $151-158$.

11 Singer P. Unsanctifying Human Life, pp 181-188, 233-246. Oxford: Blackwell, 2002.

12 Hölldobler B \& Wilson EO. Journey to the Ants. London: Harvard University Press, 1994.

13 Buber M. I and Thou. Edinburgh: Clark, 1971.

Received 1 June 2004

Accepted 5 August 2004 